\section{Lens-cleaning Tissues}

UsERs of optical instruments will be interested in details just issued by Messrs. J. Barcham Green, Ltd., the well-known makers of specialty hand-made papers, of their " 105 Lens Tissue". It is claimed that this tissue has a particularly high strength, and yet is thin, light and almost fluff-free. It absorbs moisture and oil films readily, and special precautions are taken to exclude grit and similar impurities. Its bulking properties are evident from the fact that 500 sheets make a pack 1 in. thick and weigh less than 10 per cent of the weight of the same area of an ordinary writing paper. A 'near miss' from perfection is claimed; however, since (according to the leaflet) it has been possible to achieve the longsought ideal of a $p H$ value of $7 \cdot 0$, this claim must be regarded as modest, in one respect at least.

\section{University College, Leicester: Appointments}

The Council of University College, Leicester, has announced the following appointments: Dr. A. G. Pool, senior lecturer in economics in the University of Sheffield, to the new chair of economies at the College; Dr. Z. P. Dienes, assistant lecturer in mathematics in the University of Manchester, to a lectureship in mathematics.

\section{Physical Society's Exhibition}

THE thirty-second Exhibition of Scientific Instruments and Apparatus, organised by the Physical Society, will be held during April 6-9 at the Imperial College of Science and Technology, London. Discourses will be delivered on three evenings at 6.45 p.m. as follows: Tuesday (April 6), "Studio Acoustics", by H. L. Kirke (British Broadcasting Corporation); Wednesday (April 7), "Low Temperature Physics", by Dr. K. Mendelssohn (Clarendon Laboratory, Oxford); Thursday (April 8), "The Reflecting Microscope", by Dr. C. R. Burch, W. J. Bates and Mr. K. W. Keohane (University of Bristol). Films will be shown on each of the four days: "Atomic Physics" (including Friday, April 9, at 6.45 p.m.) ; "Physies and the Film" by the British Kinematographic Society. The Exhibition will be open at the following times : April 6, 2 p.m.-9 p.m. ; April 7-9, 10 a.m.-1 p.m., 2 p.m.-8 p.m. Admission is by ticket only. Catalogues are now available.

\section{Announcements}

M. Charles Dufraisse has been elected a member of the Paris Academy of Sciences in the Section of Chemistry, in succession to the late M. Robert Lespieau.

Prof. W. T. Astbury, professor of biomolecular structure in the University of Leeds, will give the Silvanus Thompson Memorial Lecture of the British Institute of Radiology on April 16 at 8 p.m. in the Reid-Knox Hall at 32 Welbeck Street, London, W.I. The title of his address will be "The Structure of Biological Tissues as Revealed by X-Ray Diffraction Analysis and Electron Microscopy".

LORD PORTAL OF Hungerford, controller of production (atomic energy) in the Ministry of Supply, has completed his work for the production organisation and its relation with research, both at the Atomic Energy Research Establishment, Harwell, and elsewhere. He has agreed, however, to continue to act on a part-time basis, without salary, for another year.

A CONFERENCE on "The Human Factor in Industry" has been arranged by the British Association and will be held at Leamington Spa in the afternoon and evening of Saturday, May 8. Sir Henry Tizard, president of the Association and chairman of the Advisory Council on Scientific Policy, will preside at the first session, and Sir George Schuster, chairman of the Industrial Productivity Committee's Panel on Human Factors, will occupy the chair at the second. The conference will be open, without charge, to all who are interested. Further particulars will be available in due course by application to the Secretary, British Association, Burlington House, Piccadilly, W.1.

The Botanical Society of the British Isles is holding a conference on "The Study of Critical British Groups" in the Royal Horticultural Society's New Hall, Westminster, S.W.1, during April 9-10. The meeting will be held under the presidency of $\mathrm{Mr}$. J. S. L. Gilmour. Further particulars can be obtained from Miss M. S. Campbell, c/o Department of Botany, British Museum (Natural History), Cromwell Road, London, S.W.7.

THE Council of the Chemical Society will award grants from its research fund in June next. Applications, to be made on forms obtainable from the General Secretary, must be received on or before May 10. Applications from fellows of the Society will receive prior consideration. Attention is directed to the fact that the income arising from the donation of the Worshipful Company of Goldsmiths is principally devoted to the encouragement of research in inorganic and metallurgical chemistry, and that the income from the Perkin Memorial Fund is to be applied to investigations relating to problems connected with the coal tar and allied industries.

IN the article in Nature $(160,250 ; 1947)$ giving an account of the International Conference on the "Emission Spectra of the Night Sky and Auroras" that was held in the rooms of the Royal Society, Burlington House, last July, it was mentioned that the papers read would probably be published in the "Reports on Progress in Physics". Pressure on space, however, prevents this, and the Physical Society has arranged for separate publication.

Prof. W. von Buddenbrock, (16) Fronhausen/L., Talstrasse 10, U.S. Zone, Germany, is asking for reprints of papers, to enable him to proceed with the preparation of vols. 3 and 4 of his "Grundriss der vergleichenden Physiologie". It is intended to translate the work into English.

Errata. Referring to the communication "The $C / D$ Ring Union in Estrone and Equilenin" in Nature of March 20, p. 434, Dr. W. Klyne states that formulæ V and VII should have been as follow and not as shown :
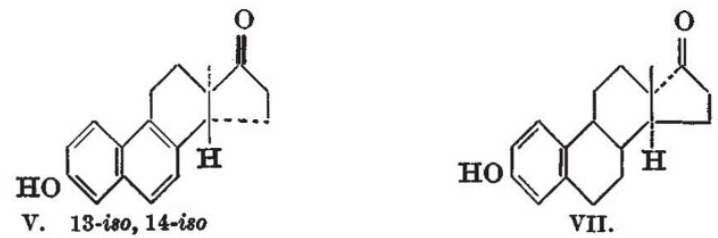